\title{
Suriye Sınırı Bölgesinde Bir Merkez Hastanenin Acil Servisine Başvuran Hastaların Profillerinin İncelenmesi
}

\author{
Demografic Analysis of Patients Admitted to Emergency Service of \\ Central Hospital in Syrian Border Area
}

\author{
Oktay AYDIN ${ }^{1}$ \\ ${ }^{1}$ Gaziantep Dr. Ersin Aslan Devlet Hastanesi Genel Cerrahi Kliniği/Gaziantep
}

\begin{abstract}
ÖZET
Ülkemiz şartlarında acil servise başvuru sayıları yüksek olup, vakaların birçoğu acil serviste takip ve tedavi edilmeye uygun olmayan hastalardan oluşmaktadır.

Suriye sınır bölgesine komşu şehrimizde Ekim 2013- Aralık 2013 tarihleri arasında hastanemiz acil servisine başvuran hastalar retrospektif alarak incelendi.

Hasta tanıları arasında ilk sirada $31.742(\% 18,8)$ hasta ile tanımlanmamış üst solunum yolu enfeksiyonu (ICD-10: J39.9), ikinci sırada $15.535(\% 9,2)$ hastaya yumuşak doku bozukluğu (ICD-10: M79.9), ve üçüncü sırada $12.845(\% 7,6)$ hasta ile akut tonsillit (ICD-10: J03.9) yer almaktadır. Travma ve yanık sebebiyle yaralanan hasta sayısı $25.863(\% 15,31)$ hastadır.

Farklı demografik dağılımları bulunan farklı bölgelerde, acil servis başvurularında hasta profilleri değişmekle birlikte yukarıda bir kısmından bahsetmeye çalıştığımı majör tanılar dominant bulunmaktadır. $\mathrm{Bu}$ tür çalışmalar ile acil servislerin hizmet kalitesi ve efektif işleyişin sağlanması hususunda daha rasyonel düzenlemeler yapılabileceği kanaatindeyiz.
\end{abstract}

Anahtar kelimeler: Acil servis, hasta profilleri, iç savaş bölgesi sinırı

\begin{abstract}
In current circumstances in country, high volume of admittion to emergency services is still a big problem.It can be realised properly when addition of the admittion of nonemergent patients considered.

In our center placed in the border of syrian civil war, 168.822 patients included the study and diagnosis evaluated retrospectively.

The most frequent diagnosis was upper respiratuary system infections 31.742 patients $(18,8 \%)$. The second frequent diagnosis was multiple lesions related with soft tissue, and the third was acute tonsillitis.Patients with trauma and burns built $15,31 \%$ of the patients.

Altough the frequent diagnosis' can be change in different regions, some common diagnosis like trauma and infections have dominancy in every region.We think that these studies like this study could help providing accurate information about profiles of emergency units and ensure building effective policies about related issues.
\end{abstract}

Keywords: Emergency unit, patient profiles, the border region of civil war
KÜ Tıp Fak Derg 2014; 16(1): 10-12

Geliş Tarihi / Received: 25.02.2014

Kabul Tarihi / Accepted: 27.03.2014
Yazışma Adresi / Correspondence: Oktay AYDIN

KÜ Tıp Fakültesi Hastanesi, KKIRIKKALE

E-posta: droktayaydin@gmail.com 


\section{GíRIŞ}

Ülkemiz şartlarında acil servise başvuru sayıları hala oldukça yüksek olup, vakaların birçoğu acil serviste takip ve tedavi edilmeye uygun olmayan poliklinik hastalarından oluşmaktadır (1). $\mathrm{Bu}$ amaçla acil servislerin efektif kullanımını sağlayabilmek açısından, acil servise başvuran hastaların demografik ve tanısal olarak ayrıntılı analiz edilmesi gerektiği görüşündeyiz. $\mathrm{Bu}$ amaçla halen iç savaşın tüm yoğunluğuyla devam ettiği Suriye sınırı bölgesinde hizmet veren hastanemizin acil servisine başvuran hastalarının demografik ve tanısal özelliklerini incelemeyi amaçladik.

\section{HASTALAR VE YÖNTEM}

Suriye sınır bölgesine komşu şehrimizde Ekim 2013Aralık 2013 tarihleri arasında hastanemiz acil servisine başvuran hastalar retrospektif alarak incelendi. Hastaların yaş, cinsiyet özellikleri, International Classification of Diseases-10 (ICD-10) tanı kodlama sistemine göre tanıları, en sık başvuru sebepleri, travma ve yanık oranları değerlendirildi.

\section{BULGULAR}

Eylül 2013- Aralık 2013 tarihleri arasında acil servise 662 farklı ICD-10 kodlu ön tanı ile 168.822 hasta değerlendirildi. Hastaların 67.148'i kadın (\%39,7), $101.674(\% 60,3)$ 'ü erkek hastadır. Hasta tanıları arasında ilk sirada $31.742 \quad(\% 18,8)$ hasta ile tanımlanmamış üst solunum yolu enfeksiyonu (ICD10: J39.9), ikinci sirada $15.535 \quad(\% 9,2)$ hastaya yumuşak doku bozukluğu (ICD-10: M79.9), ve üçüncü sirada $12.845(\% 7,6)$ hasta ile akut tonsillit (ICD-10: J03.9) yer almaktadır. Travma ve yanık sebebiyle yaralanan hasta sayısı $25.863(\% 15,31)$ hastadır. Hastalar yaş özelliklerine göre incelendiğinde en s1k başvuru yaşı 39.825 (\%23) hasta ile 21-30 yaş grubunda görülmekte olup bu grupta da ön tanıda ilk sirada üst solunum yolu enfeksiyonu gelmektedir.

\section{TARTIŞMA}

Acil servisler hastaların en fazla 48 saat tutularak tanı, tedavi ve takibinin yapıldığı servislerdir (1-5). Bununla birlikte acil servisin bilinçsizce '’hızlı çalışan bir poliklinik", olarak kullanılmaya çalışılması yoğunluğu arttırarak en çok da yine başvuran hastaları etkilemektedir. Edirne ve arkadaşları Van 100.yıl Üniversitesi Hastanesi'nde 2008 yılında yaptıkları bir çalışmada, acile başvuran hastaların \%19,5'inin uygunsuz başvuru olduğunu tespit ettiler (1). Buna göre acil servise getirilen çocukların \%52'sinin gerçek acil, \%11'i acil olduğu düşünülerek getirilenler ve \%37'sinin ise acil olmayan hastalardan oluştuğunu saptadılar. Buradan hareketle biz de aynı şekilde en önemli sorunlardan birinin acil servise uygunsuz başvuru olduğu fikrini paylaşıyoruz.

Çalışmamızda, acil servis profiline hakim grupları kısaca incelemek gerekirse, öncelikle travma vakalarından söz etmek uygun olacaktır. Travma genç hastalığı olup, 1-44 yaş arası ölümlerin sebepleri arasında ilk sıradadır (6). Ülkemizde acil servise başvuran hastaların ortalama \%7-20'sinin travma hastası olduğu bilinmektedir. Bizim çalışmamızda bu oranın oldukça yüksek olmasının, daha önce de açıklandığı gibi sınır bölgesinde, çatışmalara yakın bir mesafede hizmet veriyor olmaktan kaynaklanan oransal bir artış olduğunu düşünmekteyiz. Travma hastalarında hâkim cinsiyetin erkek olması, literatürle uyumlu olduğu kadar, yine bu sebebi destekler niteliktedir.

$\mathrm{Bu}$ noktada yine adli olgular da acil servise başvuran olguların büyük bir kısmını oluşturmaktadır. Türkmen ve arkadaşlarının 2005 yılında yaptıkları bir çalışmada, acil serviste adli vaka sayısının tüm hastalara oranının, ortalama 2'şer yıllık aralıklarla \%43, \%53 ve $\% 76$ olarak artış gösterdiği tespit edilmiştir (7). Bizim 
çalışmamızdaki adli vaka oranları göz önüne alındığında, hekimin sorumlulukları arasında adli vakaları tespit ve raporla belgelendirme işinin de bulunduğunu hatırlatmak isteriz. Türkmen ve arkadaşlarına, hastaların kişisel haklarının kaybolmaması ve gereksiz mağduriyetlerden kaçınma noktasında hekimlere büyük iş düştüğü hususunda katılmaktayız.

Adli vakaların içinde büyük bir bölümü oluşturan zehirlenmeler de yine çalışmamızda yer tutan antitelerden biridir (8). Tüm alanlarda ilaç sanayiinin gelişmesi neticesinde zehirlenme olgularında da artış gözlenmektedir. Zehirlenmelerin niteliği yöresel özellikler, eğitim düzeyi, gelenekler, sosyoekonomik durum, yaş, mevsim ve cinsiyet gibi parametrelere bağlı değişmekle birlikte acil ve etkin bir acil servis müdahalesi hayati önemdedir (8).

Son olarak acil servis başvurularında büyük önem arz eden yanıklar da yine en kısa sürede ve titizlikle ele alınması gereken konulardan biridir. Kocatürk ve arkadaşlarının yaptığı bir çalışmada hastaların \%34'ünün 5 yaşın altındaki çocuk ve \%65,4'ü ev ortamında sıcak bir maddenin dökülmesi ile meydana geldiği saptanmıştır (9). Bu bakımdan ev kazaları konusunda halkı bilinçlendirici çalışmalar yapılmasını sağlayacak halk sağlığı disiplinlerinin de bu konuda en az tedavide acil hekiminin aldığı sorumluluk kadar önemli olduğu görüşündeyiz.

Farklı demografik dağılımları bulunan farklı bölgelerde, acil servis başvurularında hasta profilleri değişmekle birlikte yukarıda bir kısmından bahsetmeye çalıştığımız majör tanılar dominant bulunmaktadır. Bu tür çalışmalar ile acil servislerin hizmet kalitesi ve efektif işleyişin sağlanması hususunda daha rasyonel düzenlemeler yapılabileceği kanaatindeyiz.

\section{KAYNAKLAR}

1. Edirne T, Edirne Y, Atmaca B, Keskin S. Yüzüncü Y1l Üniversitesi Tip Fakültesi acil servis hastalarının özellikleri. Van Tıp Dergisi. 2008; 15 (4): 107-11.

2. Bezzina AJ, Smith PB, Cromwell D, Eagar K.Primary care patients in the emergency department: who are they? A review of thedefinition of the 'primary care patient' in the emergency department. Emerg Med Australas. 2005; 17: 472-79.

3. Coleman P, Irons R, Nicholl J. Will alternative immediate care services reduce demands for nonurgent treatment at accident and emergency? Emerg Med J. 2001; 18: 482-87.

4. Derlet RW. Overcrowding in emergency departments: increased demand and decreased capacity. Ann Emerg Med. 2002; 39: 430-32.

5. Lee A, Lau FL, Hazlett CB, Kam CW, Wong P, Wong TW, Chow S. Factors associated withnonurgent utilization of Accident and Emergency services: a case-control study in Hong Kong. Soc Sci Med. 2000; 51: 1075-85.

6. Akoğlu H, Denizbaşı A, Ünlüer E, Güneysel Ö, Onur Ö. Marmara Üniversitesi Hastanesi acil servisine başvuran travma hastalarının demografik özellikleri. Marmara Med J. 2005; 18(3): 113-22.

7. Türkmen N, Akgöz S, Çoltu A, Ergin N. Uludağ üniversitesi tıp fakültesi acil servisine başvuran adli olguların değerlendirilmesi. Uludağ Üniversitesi T1p Fakültesi Dergisi. 2005; 31(1): 25-9.

8. Sönmez E, Karakuş A, Çavuş UY, Civelek C, İpek G, Zeren C. Bir üniversite hastanesi acil servisine başvuran zehirlenme olgularının değerlendirilmesi. Dicle Tıp Dergisi. 2012; 39(1): 21-6.

9. Kocatürk BK, Teyin M, Balcı Y, Eşiyok B. Osmangazi Üniversitesi Hastanesi Acil Servisi'ne başvuru yapmış yanık olgularının değerlendirilmesi. Türkiye Klinikleri J Med Sci. 2005; 25: 400-06. 